\title{
SELECTION OF PHOTOVOLTAIC SOLAR POWER PLANT PROJECTS USING ANP
}

\author{
Pablo Aragonés-Beltrán $*^{\mathrm{a}}$ \\ E-mail: aragones@dpi.upv.es \\ Juan P. Pastor-Ferrando ${ }^{\mathrm{a}}$ \\ E-mail: jppastor@dpi.upv.es \\ Fidel Chaparro-González ${ }^{\mathrm{b}}$ \\ E-mail: fchaparro.des@elecnor.es \\ R. Poveda Bautista ${ }^{\mathrm{a}}$ \\ E-mail: ropobau@dpi.upv.es \\ ${ }^{a}$ Department of Engineering Projects \\ ${ }^{\mathrm{b}}$ Department of Business \\ Universidad Politécnica de Valencia. \\ Camino de Vera s/n, 46022 Valencia, SPAIN.
}

\begin{abstract}
This paper presents an analysis to simplify a complex model, based on the Analytic Network Process (ANP); to select photovoltaic (PV) solar power projects. These projects follow a long management and execution process from plant site selection to plant start-up. As a consequence, there are many risks of time delays and even of project stoppage. In a previous work a top manager of an important Spanish company decided on the best PV project (from four alternative projects) to invest based on risk minimization, using a complex ANP model (54 elements grouped into different clusters). This model needs to be simplified in order to solve similar selection problems in future.

To identify which risks have to be eliminated from the original model is a difficult task. In this work two ways for doing this identification are proposed: in the fist way we select the 25 more important risks obtained by the original ANP model; in the second way we asked the decision maker to select the 25 risks that he considers have to be included in the future selection problems. The differences between both models are analyzed.

In both cases the original ANP model, including its influences between elements of the network, has been simplified using Superdecisions software.
\end{abstract}

Keywords: Analytic network process (ANP), project selection, photovoltaic (PV) solar power projects

\section{Introduction}

Spain has very good conditions for the development of photovoltaic solar power systems due mainly to the high mean daily radiation and the high number of sunny days in most parts of the country. For this reason, the Administration and companies working in the sector are developing policies and investing in photovoltaic solar power systems (Salas and Olias, 2008).

${ }^{*}$ Corresponding author 
The present paper analyzes the problem for the top manager, acting as Decision Maker (DM), of an important solar power investment company to establish a priority order among different projects for the development of a photovoltaic solar power plant. The decision problem presented here is highly complex because in addition to economic profitability, the risks involved in the development, construction, execution and maintenance of the plant are relevant factors in the decision making process. Investment companies that execute the project and further exploit the installations cannot have their resources inactive while waiting for the corresponding construction approval and execution permits, which may get delayed, or depend on long negotiations with the power supply company.

In a previous work the DM, assisted by the research team of the Department of Engineering Projects of the Polytechnic University of Valencia, playing the role of Analysis Team (AT), solved the following decision-making problem: "Given a number of photovoltaic power investment projects that are known to be profitable for the company, establish project priority based on project risk levels and execution time delays". Four specific projects were prioritized and fifty risks were identified. These risks were grouped into clusters and, following the ANP method, the influences between elements and between clusters were identified and prioritized. In the following we will refer to this model as complex model.

The problem raised by the DM was that this model was too complex to use in future similar decision making problems and he asked the AT to simplify it. The way to do this is not an easy task. The results of the complex model showed us the prioritization between alternatives and the weights of the risks but these weights depend on the specific projects that have been considered. In this work two ways for doing this identification are proposed: in the fist way we select the 25 more important risks obtained by the original ANP model; in the second way we asked the decision maker to select the 25 risks that he considers have to be included in the future selection problems.

The rest of the paper is organized as follows. Firstly, Section 2 introduces the complex model and presents the main results. Section 3 describes the simplification process and Section 4 presents the main conclusions drawn from this research and future works.

\section{Description of the complex model}

The steps of the decision-making process were the following:

i. Analysis of the project stages involved in the development of a PV solar power plant.

ii. Risk Identification and classification.

iii. Specification of the Project portfolio.

iv. ANP modelling of the decision-making problem.

v. ANP prioritization and conclusions.

At the first step the process of developing a photovoltaic solar power plant was analyzed from the selection of the best plant site to the execution, exploitation and maintenance of the plant. This analysis allowed the DM to identify project delay or stoppage risks for each stage of the process. At step ii) fifty risks were identified and grouped into eleven clusters: political, technical associated with plant site, technical associated with technology, economic associated with plant exploitation, economic associated with the obtaining of the plant start-up permits, economic associated with plant site, economic associated with technology, macroeconomic, time delays, legal and social risks.

In step iii) the DM identified the projects that were used as alternatives in the decision process. Project selection was based on criteria of economic profitability, and technical and environmental feasibility. Four projects with different characteristics and plant location were finally selected. 
The ANP model of the decision making process was built in step iv) following the main steps of this method (Saaty, 2001). The decision model was built with the support of Super Decisions v1.6.0. software (www.superdecisions.com). The results obtained are shown in Tables 1 and Table 2 (in Table 1 only the first twenty five classified weights are included ordered by preference/influence).

\begin{tabular}{|c|c|c|c|}
\hline & Risks & $\begin{array}{c}\text { ANP } \\
\text { complex model } \\
\text { influence }\end{array}$ & $\begin{array}{c}\text { ANP } \\
\text { complex model } \\
\text { influence } \\
\text { renormalized }\end{array}$ \\
\hline $\mathrm{C} 01$ & Changes in the energy policy & 0.118 & 0.137 \\
\hline $\mathrm{C} 50$ & Social consequences resulting from land acquisition & 0.105 & 0.121 \\
\hline $\mathrm{C} 40$ & Delays in the obtaining of the EIS & 0.065 & 0.075 \\
\hline C47 & Legislative changes in the EIS & 0.063 & 0.073 \\
\hline C48 & Thefts & 0.063 & 0.073 \\
\hline $\mathrm{C} 02$ & Local body Approval & 0.060 & 0.069 \\
\hline C19 & Revenue estimates based on effective solar radiation time & 0.045 & 0.052 \\
\hline $\mathrm{C} 39$ & Delays in the obtaining of the Local Body Approval & 0.041 & 0.048 \\
\hline $\mathrm{C} 30$ & Costs due to lack of consistency in solar tracker selection & 0.031 & 0.035 \\
\hline $\mathrm{C} 18$ & Performance losses & 0.028 & 0.033 \\
\hline $\mathrm{C} 22$ & Flood prevention works & 0.026 & 0.030 \\
\hline $\mathrm{C} 43$ & Changes in the general legislation & 0.025 & 0.029 \\
\hline $\mathrm{C} 38$ & $\begin{array}{l}\text { Delays in the signature of the agreement with the Electricity } \\
\text { supply company }\end{array}$ & 0.023 & 0.026 \\
\hline $\mathrm{C} 49$ & Vandalism & 0.021 & 0.024 \\
\hline $\mathrm{C} 37$ & Delays in the obtaining of the plant Start-up Act & 0.016 & 0.019 \\
\hline $\mathrm{C} 15$ & Plant operation costs & 0.016 & 0.019 \\
\hline $\mathrm{C} 42$ & Changes in the specific legislation & 0.015 & 0.018 \\
\hline $\mathrm{C} 21$ & Earthworks resources & 0.014 & 0.017 \\
\hline $\mathrm{C} 34$ & Changes in energy prices & 0.014 & 0.016 \\
\hline $\mathrm{C} 46$ & $\begin{array}{l}\text { Obtaining of the Registration in the Register of Production } \\
\text { Facilities in special Regime }\end{array}$ & 0.013 & 0.015 \\
\hline $\mathrm{C} 03$ & Obtaining of the Construction License & 0.013 & 0.015 \\
\hline C16 & Corrective maintenance costs & 0.012 & 0.014 \\
\hline $\mathrm{C} 45$ & Legislative changes in the Plant Start-up Act & 0.012 & 0.014 \\
\hline $\mathrm{C} 28$ & Costs due to wrong selection of PV cell & 0.012 & 0.014 \\
\hline \multirow[t]{2}{*}{$\mathrm{C} 09$} & Development of new PV solar power systems & 0.011 & 0.013 \\
\hline & Total & 0.862 & 1 \\
\hline
\end{tabular}

Table 1.- First twenty five risks in the ANP complex model 


\begin{tabular}{|l|l|}
\hline A3 & 0.144 \\
\hline A4 & 0.159 \\
\hline A1 & 0.285 \\
\hline A2 & 0.412 \\
\hline
\end{tabular}

Table 2.- Alternative ranking in the ANP complex model

Let's now mention an important consideration that affected the whole decision analysis process: although the main goal of the problem was to select the project with the lowest risk, when formulating the comparison matrices to weigh the risks according to Saaty's 1-9 scale, the highest weight was obtained by the risk with the highest score; i.e. when comparing the importance of two risks, it was easier for the DM to score 9 a risk that was extremely more important than another risk with which it was compared. In this sense, for the risk-based assessment of the alternatives, the DM thought it better to consider a higher risk alternative more important than the other alternatives under comparison. And this is the reason why the alternative with a higher score also obtained a higher risk value. Thus, in the results of ANP the alternative with the highest score is also the alternative with the highest risk value. This is why the formulation of the main goal of the problem states "to minimize risks". However, for the final decision and taking into consideration all risks, the alternative with the lowest score is considered a better option, and therefore the project globally assessed as the alternative with the lowest risk value is the alternative finally selected as the best option.

\section{Simplification process}

The DM was pleased with the results of the complex model. However, he realized how difficult it was to apply this model to future similar cases. So he asked the AT to simplify this complex model. The main problem was to select the main risks to take into account in future prioritizations. The AT observed that the twenty five more influential risks account for $86.2 \%$ of the total weight. The AT considered better to build up a new model with twenty five risks.

The second problem was which twenty five risks to select. At this stage two different ways to do this selection seemed reasonable. The first one was to select directly the first twenty five more influential risks obtained in the complex model (Table 3). The second one was to ask the DM to select the twenty five risks to be selected in future similar decision making problems (Table 4). 


\begin{tabular}{|c|c|c|}
\hline \multirow{3}{*}{ POLITICAL } & $\mathrm{C} 01$ & Changes in the energy policy \\
\hline & $\mathrm{C} 02$ & Obtaining of the Local body Approval \\
\hline & $\mathrm{C} 03$ & Obtaining of the Construction License \\
\hline $\begin{array}{l}\text { TECHNICAL ASSOCIATED WITH } \\
\text { TECHNOLOGY }\end{array}$ & $\mathrm{C} 09$ & Development of new PV solar power systems \\
\hline \multirow{3}{*}{$\begin{array}{l}\text { ECONOMIC ASSOCIATED WITH } \\
\text { PLANT EXPLOITATION }\end{array}$} & $\mathrm{C} 15$ & Plant operation costs \\
\hline & $\mathrm{C} 16$ & Corrective maintenance costs \\
\hline & $\mathrm{C} 18$ & Performance losses \\
\hline \multirow{3}{*}{$\begin{array}{l}\text { ECONOMICS ASSOCIATED WITH } \\
\text { PLANT SITE }\end{array}$} & C19 & $\begin{array}{l}\text { Revenue estimation based on effective solar radiation } \\
\text { time }\end{array}$ \\
\hline & $\mathrm{C} 21$ & Earthworks resources \\
\hline & $\mathrm{C} 22$ & Flood prevention works \\
\hline \multirow{2}{*}{$\begin{array}{l}\text { ECONOMIC ASSOCIATED WITH } \\
\text { TECHNOLOGY }\end{array}$} & $\mathrm{C} 28$ & Costs due to wrong selection of PV cell \\
\hline & C30 & $\begin{array}{l}\text { Costs due to lack of consistency in solar tracker } \\
\text { selection }\end{array}$ \\
\hline MACROECONOMIC & C34 & Changes in energy prices \\
\hline \multirow{4}{*}{ TIME DELAYS } & C37 & Delays in the obtaining of the plant Start-up Act \\
\hline & $\mathrm{C} 38$ & $\begin{array}{l}\text { Delays in the signature of the agreement with the } \\
\text { Electricity supply company }\end{array}$ \\
\hline & C39 & Delays in the obtaining of the Local Body Approval \\
\hline & $\mathrm{C} 40$ & Delays in the obtaining of the EIS \\
\hline \multirow{5}{*}{ LEGAL } & $\mathrm{C} 42$ & Changes in the specific legislation \\
\hline & $\mathrm{C} 43$ & Changes in the general legislation \\
\hline & $\mathrm{C} 45$ & Legislative changes in the Plant Start-up Act \\
\hline & C46 & $\begin{array}{l}\text { Obtaining of the Registration in the Register of } \\
\text { Production Facilities in special Regime }\end{array}$ \\
\hline & C47 & Legislative changes in the EIS \\
\hline \multirow{3}{*}{ SOCIAL } & $\mathrm{C} 48$ & Thefts \\
\hline & $\mathrm{C} 49$ & Vandalism \\
\hline & C50 & Social consequences resulting from land acquisition \\
\hline
\end{tabular}

Table 3.- First twenty five risks from the ANP complex model 


\begin{tabular}{|c|c|c|}
\hline \multirow{3}{*}{ POLITICAL } & $\mathrm{C} 01$ & Changes in the energy policy \\
\hline & $\mathrm{C} 02$ & Obtaining of the Local body Approval \\
\hline & $\mathrm{C} 03$ & Obtaining of the Construction License \\
\hline $\begin{array}{l}\text { TECHNICAL ASSOCIATED WITH } \\
\text { PLANT SITE }\end{array}$ & $\mathrm{C} 04$ & Technological adequacy to climate change \\
\hline \multirow{3}{*}{$\begin{array}{l}\text { TECHNICAL ASSOCIATED WITH } \\
\text { TECHNOLOGY }\end{array}$} & $\mathrm{C} 09$ & Development of new PV solar power systems \\
\hline & $\mathrm{C} 13$ & Connection to the electric grid \\
\hline & $\mathrm{C} 14$ & Possibility of alternative power generation systems \\
\hline $\begin{array}{l}\text { ECONOMIC ASSOCIATED WITH } \\
\text { PLANT EXPLOITATION }\end{array}$ & $\mathrm{C} 15$ & Plant operation costs \\
\hline \multirow{2}{*}{$\begin{array}{l}\text { ECONOMIC ASSOCIATED WITH THE } \\
\text { OBTAINING OF THE PLANT START- } \\
\text { UP PERMITS }\end{array}$} & $\mathrm{C} 24$ & Costs of connection to electric grid \\
\hline & $\mathrm{C} 26$ & Possibility of constructing the power connection line \\
\hline \multirow{3}{*}{ MACROECONOMIC } & $\mathrm{C} 31$ & Obtaining of bank financing \\
\hline & $\mathrm{C} 33$ & Changes in the price of money \\
\hline & $\mathrm{C} 34$ & Changes in energy prices \\
\hline \multirow{6}{*}{ TIME DELAYS } & $\mathrm{C} 35$ & $\begin{array}{l}\text { Delays in the construction of the power connection } \\
\text { line }\end{array}$ \\
\hline & $\mathrm{C} 36$ & $\begin{array}{l}\text { Delays in the obtaining of the administration approval } \\
\text { for the construction of the line }\end{array}$ \\
\hline & $\mathrm{C} 37$ & Delays in the obtaining of the plant Start-up Act \\
\hline & $\mathrm{C} 39$ & Delays in the obtaining of the Local Body Approval \\
\hline & $\mathrm{C} 40$ & Delays in the obtaining of the EIS \\
\hline & $\mathrm{C} 41$ & Delays in the obtaining of the construction license \\
\hline \multirow{5}{*}{ LEGAL } & $\mathrm{C} 42$ & Changes in the specific legislation \\
\hline & $\mathrm{C} 44$ & $\begin{array}{l}\text { Legislative changes in the Administrative } \\
\text { Authorization of the power distribution line }\end{array}$ \\
\hline & $\mathrm{C} 45$ & Legislative changes in the Plant Start-up Act \\
\hline & $\mathrm{C} 46$ & $\begin{array}{l}\text { Obtaining of the Registration in the Register of } \\
\text { Production Facilities in special Regime }\end{array}$ \\
\hline & $\mathrm{C} 47$ & Legislative changes in the EIS \\
\hline SOCIAL & $\mathrm{C} 50$ & Social consequences resulting from land acquisition \\
\hline
\end{tabular}

Table 4.- Twenty five risks chosen by the DM

\section{Simplified models and results}

Both models have to preserve current cluster structure and the influences established in the complex model. If this structure changes the judgments made by DM should be reconsidered. The AT simplified the complex model with the support of Superdecisions software. Figure 1 and Figure 2 show these two simplified models. Table 5 shows the comparative results and Table 6 shows Hadamard's compatibility index. 


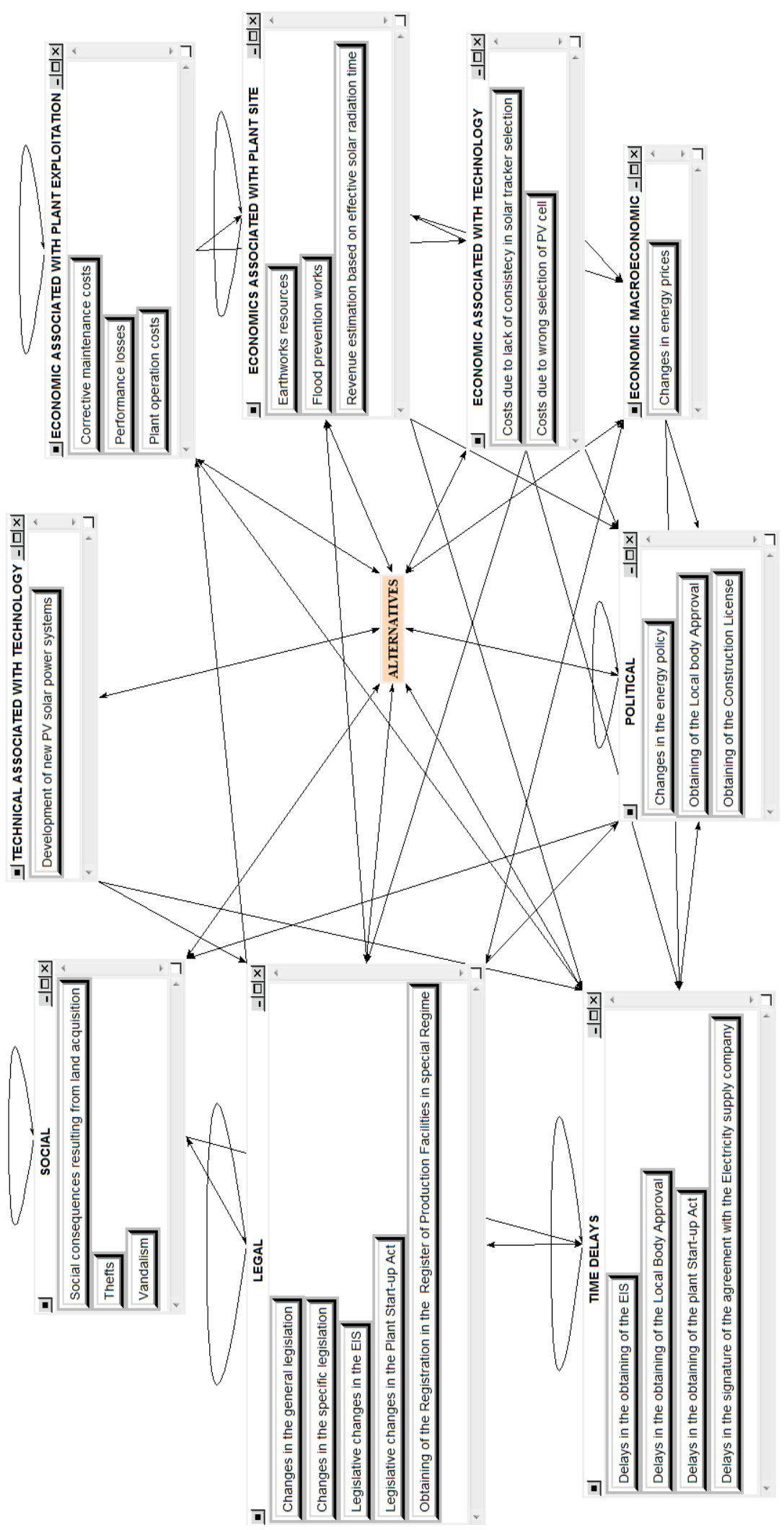

Figure 1.- Simplified model with twenty five risks selected by the ANP complex model 


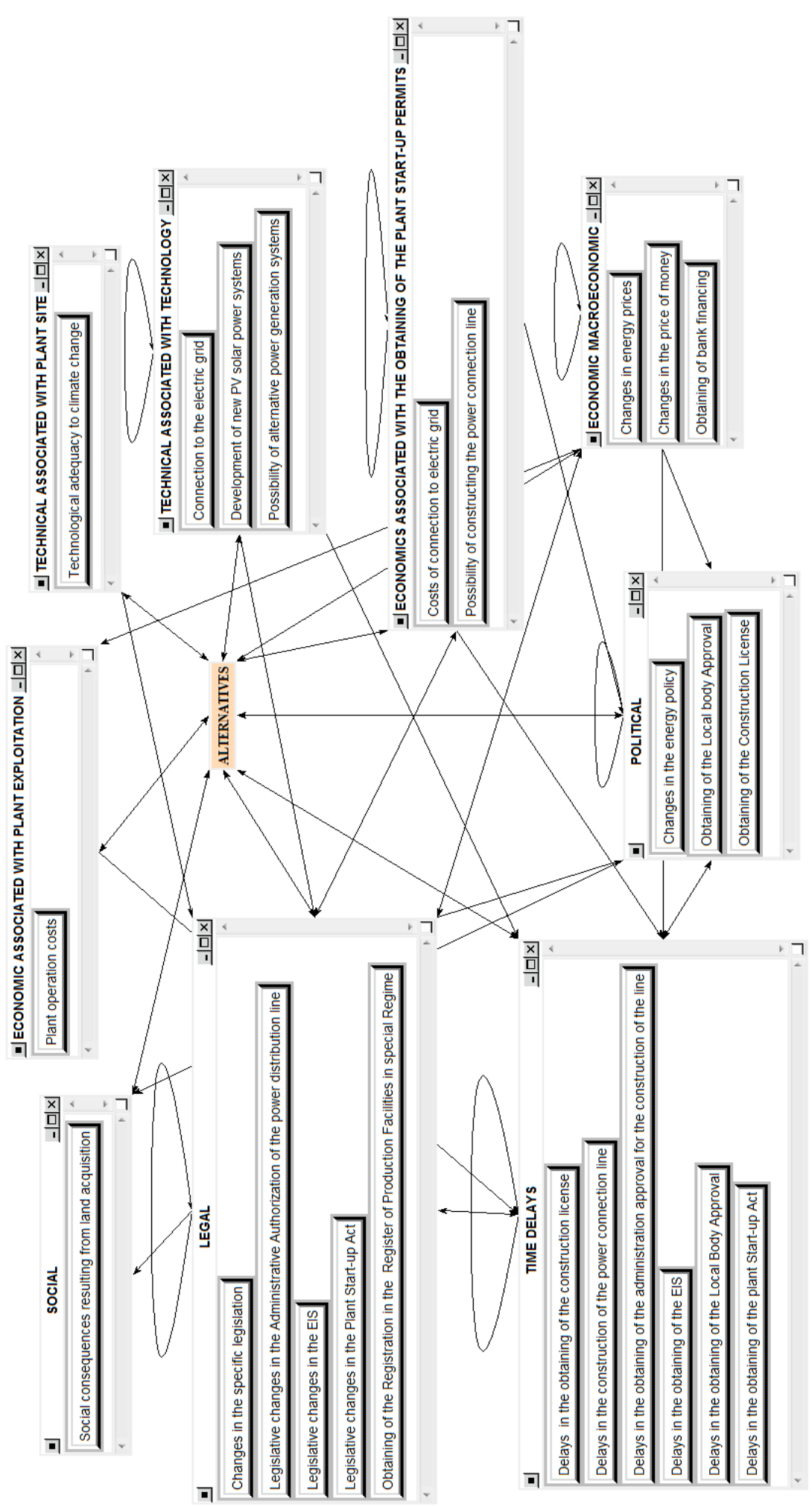

Figure 2.- Simplified model with twenty five risks selected by the DM 


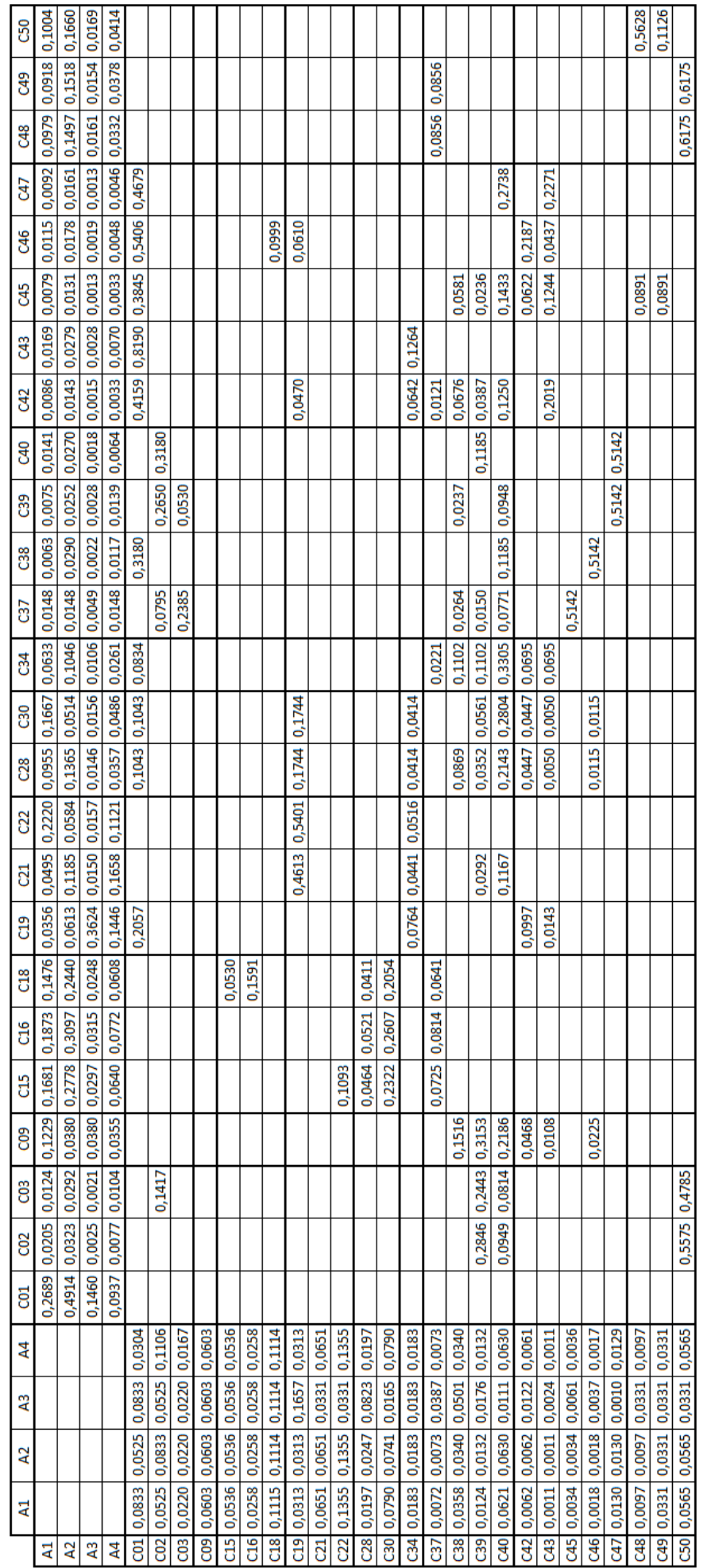

a)

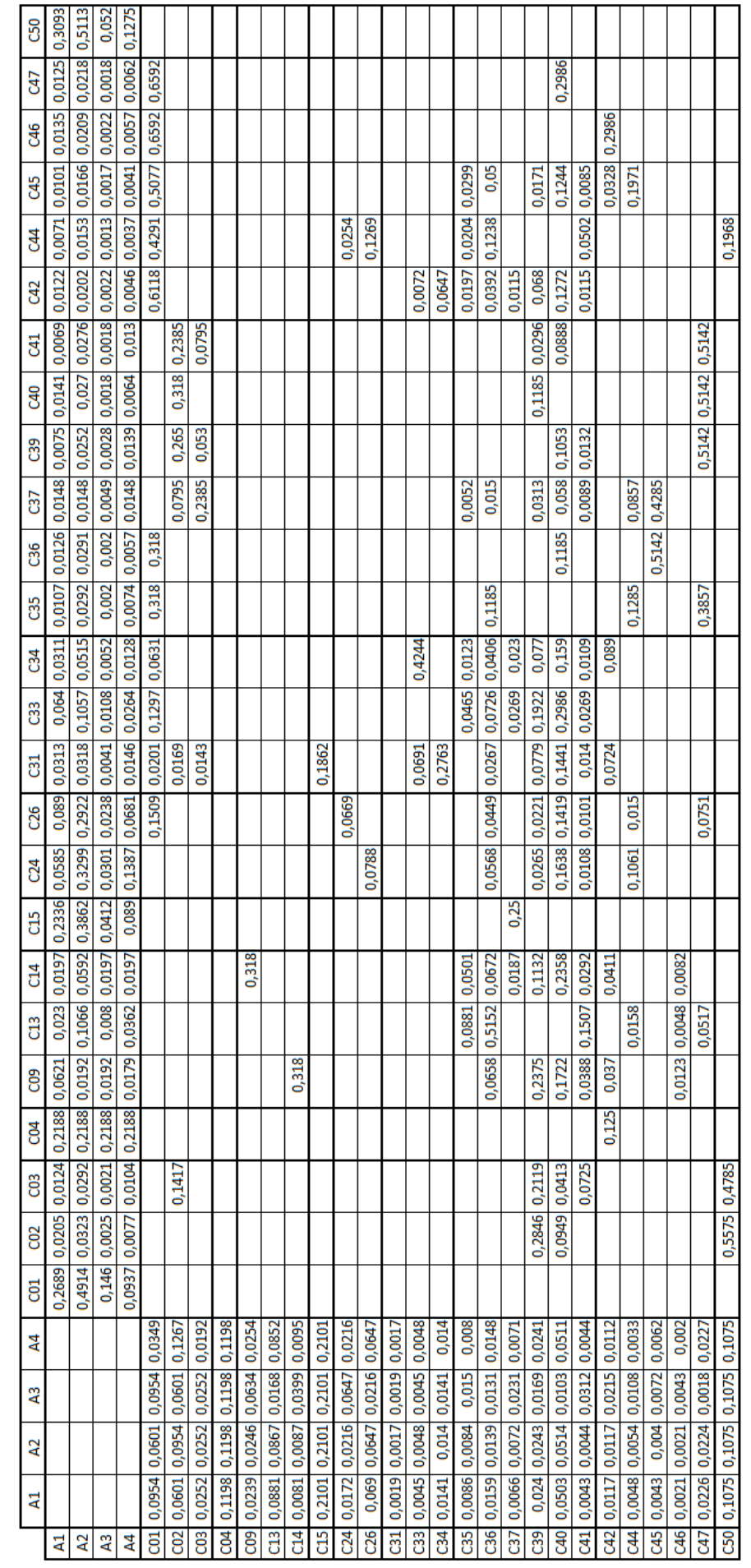

b)

Table 6.- Weighted supermatrix: a) 25 ANP, b) 25 DM 


\begin{tabular}{|l|l|l|l|l|l|}
\hline \multicolumn{2}{|c|}{25} & \multicolumn{2}{c|}{ ANP DM } & \multicolumn{2}{c|}{ ANP COMPLEX } \\
\hline A4 & 0.145 & 0.106 & A3 & 0.144 & A3 \\
\hline A3 & 0.146 & 0.133 & A4 & 0.159 & A4 \\
\hline A1 & 0.288 & 0.278 & A1 & 0.285 & A1 \\
\hline A2 & 0.421 & 0.483 & A2 & 0.412 & A2 \\
\hline C50 & 0.122 & 0.145 & C01 & 0.137 & C01 \\
\hline C01 & 0.116 & 0.107 & C50 & 0.121 & C50 \\
\hline C40 & 0.083 & 0.100 & C47 & 0.075 & C40 \\
\hline C48 & 0.074 & 0.091 & C40 & 0.073 & C47 \\
\hline C47 & 0.071 & 0.089 & C02 & 0.073 & C48 \\
\hline C02 & 0.066 & 0.087 & C15 & 0.069 & C02 \\
\hline C19 & 0.058 & 0.060 & C39 & 0.052 & C19 \\
\hline C39 & 0.049 & 0.050 & C04 & 0.048 & C39 \\
\hline C22 & 0.041 & 0.033 & C13 & 0.035 & C30 \\
\hline C30 & 0.037 & 0.033 & C36 & 0.033 & C18 \\
\hline C18 & 0.037 & 0.030 & C45 & 0.030 & C22 \\
\hline C49 & 0.025 & 0.028 & C26 & 0.029 & C43 \\
\hline C43 & 0.024 & 0.026 & C37 & 0.026 & C38 \\
\hline C38 & 0.021 & 0.021 & C03 & 0.024 & C49 \\
\hline C34 & 0.019 & 0.015 & C09 & 0.019 & C37 \\
\hline C21 & 0.019 & 0.015 & C42 & 0.019 & C15 \\
\hline C09 & 0.019 & 0.014 & C44 & 0.018 & C42 \\
\hline C15 & 0.019 & 0.013 & C41 & 0.017 & C21 \\
\hline C37 & 0.018 & 0.013 & C24 & 0.016 & C34 \\
\hline C42 & 0.016 & 0.010 & C14 & 0.015 & C46 \\
\hline C16 & 0.014 & 0.009 & C35 & 0.015 & C03 \\
\hline C03 & 0.014 & 0.007 & C34 & 0.014 & C16 \\
\hline C28 & 0.013 & 0.005 & C33 & 0.014 & C45 \\
\hline C46 & 0.013 & 0.001 & C46 & 0.014 & C28 \\
\hline C45 & 0.010 & 0.001 & C31 & 0.013 & C09 \\
\hline
\end{tabular}

Table 5.- Results

\begin{tabular}{|l|l|l|}
\cline { 2 - 3 } \multicolumn{1}{c|}{} & ANP DM & 25 ANP \\
\hline ANP Complex & 1.03058 & 1.00218 \\
\hline ANP DM & - & 1.02703 \\
\hline
\end{tabular}

Table 6.- Hadamard's compatibility index 
The prioritization of the alternatives gives similar results in the ANP complex and 25 DM models (compatibility index $=1.002$ ). The elimination of the less influential criteria hardly affects the results in the complex model. Although a change in the position of alternatives A3 and A4 can be observed, the differences in the priorities of these two alternatives are meaningless. In the ANP complex model A3 obtains better results than A4, and in the 25 ANP model both alternatives get similar values.

When comparing alternative prioritization in the ANP DM model and in the other two models, alternative A3 gets better values in the ANP DM model. The compatibility index is acceptable (1.030 in the comparison between the ANP DM model and the ANP complex model, and 0.027 in the comparison between the ANP DM model and the 25 ANP model). Note that the three models show similar results.

As regards criteria weights, similar weight values are obtained in the ANP complex and 25 ANP models. The elimination of the 25 less influential criteria hardly affects these results. However, the comparison of the weights in these two models with the weights of the ANP DM model reveals significant differences, as some criteria change their position in the ranking order.

\section{Conclusions}

The process of model simplification is not an easy task. Although the elimination of the less influential criteria may seem the easiest procedure for model simplification and in the present case study provides a better compatibility index, this method has the drawback of being based on the selection of the most influential criteria for a particular situation. However, the initial idea was to develop a model of criteria and influences applicable to similar decision problems.

Based on the findings of the present analysis, we recommend asking the DM in each new decision problem about which criteria should be included in or removed from the original model, and using the complex model as a compatibility test for the simplified model. The results suggest that although the compatibility index values are worse when using the criteria selected by the DM, the compatibility index obtained is acceptable. The DM possesses a deep understanding of the problem and therefore his criteria selection includes the most influential factors commonly found in this type of decision problems.

The structure of the clusters was not modified as it had involved asking the DM again about the selected criteria. If, for example, the economic and technical criteria had been unified, the new influences over other elements would have had to be calculated. And this would have involved re-constructing part of the process

The general conclusion that can be drawn from the present study is that in ANP the identification and clustering of criteria is a key step that affects the final results obtained in the process. Therefore, it is essential to perform this step carefully and that the DM applies his knowledge and experience to the identification of the criteria to take into account in the decision problem

\section{References}

Salas V.. Olias E.(2009). Overview of the photovoltaic technology status and perspective in Spain. Renewable \& Sustainable Energy Reviews 13 (5). 1049-1057. Doi: 10.1016/j.rser.2008.03.011.

Saaty. T.L. (2001). Decision making with independence and feedback: The Analytic Network Process. RWS Publications: Pittsburgh; 2001. 